\title{
REPRODUKSI NARASI TENTANG KEPAHLAWAN SOEHARTO: STUDI REPRESENTASI DI MUSEUM H.M. SOEHARTO
}

\author{
Ayu Dipta Kirana \\ Museum Sono Budoyo, Yogyakarta, \\ e-mail: dipta.kirana@gmail.com
}

\begin{abstract}
Museum have a vision to become a media with the message and knowledge to share with visitor. The vision of museum could be a knowledge of museum that representing national identity, culture, history, or biography of public figure. The representation from one of famous figure in Indonesia could we seen in museum that called Museum H.M. Soeharto. These articles aim to discover how the museum will work on Sang Bapak's representation in museum's narration which are shown not only by a very lengthy text display but also on the attribute or object that scattered around in the museum's yard. A whole object collection in museum will work based from the vision and aim of the museum. In the museum context it called musealisation. It means that all the object collections are separated from their social context in real life then it enters the context of museum so it will works based from the story or vision that made by what curator want and re-create the hero's narration of Soeharto.
\end{abstract}

Keywords: Museum, Representation of Soeharto, and Hero

\section{PENGANTAR}

"Orang yang kemari (museum), kebanyakan pecintanya. Kebanyakan orang tuatua-pensiunan, petani, pedagang. Mengeluh ini itu tentang keadaan yang tidak lagi damai. Sekarang kampung sering berantem ribut..." Pak Bibit seorang bapak tua yang usianya telah mencapai 70 tahun. Ia bertugas sebagai penjaga di Museum H.M. Soeharto. Tugas menjaganya lebih seperti penerima buku tamu. Duduk di sebuah kursi panjang, sambil menyapa pengunjung yang datang. Berbasa-basi menanyakan pengunjung berasal dari mana sembari menyilakan untuk mengisi buku tamu yang sudah tampak dipenuhi nama-nama orang dari berbagai daerah.

Pengunjung museum berdatangan dari kota-kota besar maupun dari desadesa sekitaran wilayah Kemusuk. Ada yang datang dari Jakarta, Purworejo, 
Kalimantan, Sumatera hingga turis asing dari Amerika. Selain karena kepopuleran sosok Soeharto yang menjadi daya tarik, museum ini pun hadir sebagai wahana rekreasional yang menarik minat banyak pengunjung. Terlebih lagi mereka tidak dipungut bayaran untuk masuk ke ruang pameran atau hanya sekedar duduk-duduk di pendopo mencari angin.

Pak Bibit menceritakan sejarah singkat kisah hidup Soeharto yang pernah tinggal di Desa Kemusuk - tempat lahirnya ini, menaiki kerbau bermain di pematang sawah bersama temannya. Soeharto lahir di tahun 1921 di Desa Kemusuk ketika listrik belum masuk dan jalan masih berupa belum diaspal (Abdulgani-Knapp, 2007: 18). Tinggal di daerah kultur pedesaan, Soeharto menghabiskan masa kecilnya bergelut dengan kerja menanam padi serta menggembala ternak. Tempat tinggal Soeharto kecil kini kemudian disulap menjadi sebuah tempat memorial untuk mengenang Soeharto yang disebut dengan 'Museum Memorial Jenderal Besar Soeharto'.

Museum H.M. Soeharto ini terletak di Desa Kemusuk, Argomulyo, Sedayu, Kabupaten Bantul, DIY. Desa Kemusuk kini tak lagi tempat terpencil seperti ketika Soeharto kecil masih tinggal di situ. Desa ini telah berubah menjadi desa yang lebih modern, akan tetapi kita masih dapat mencapai hektaran sawah yang terbentang di sepanjang perjalanan menuju museum ini. Suasana pedesaan begitu kental terasa di Desa Kemusuk ini.

Soeharto ialah bekas presiden kedua RI. Figurnya selalu menjadi buah bibir yang memantik pro dan kontra. Dia selalu dicintai namun sekaligus pula dibenci karena selama memimpin 32 tahun banyak hal yang telah ia bangun untuk negara namun juga tak sedikit tatanan sistem ia rubah untuk kepentingan pribadinya. Hampir 21 tahun setelah Soeharto turun dari jabatannya menandai era reformasi di republik ini. Ingatan manusia berkejaran dengan waktu hingga perlahan sosoknya kian dilupakan. Sentimen-sentimen negatif yang gencar ditujukan kepadanya di awalawal era reformasi kini gaungnya kian memudar, bahkan hilang sama sekali.

Saya masih ingat pada sekitar awal tahun 2012, tiba-tiba muncul entah dari mana meme Soeharto yang mengatakan "Piye Bro, isih enak jamanku tho?" Orang-orang sangat menyukai punchline tersebut karena seolah menjadi refleksi mengenai kehidupan yang begitu sulit belakangan ini. Orang-orang, seperti yang diungkapkan oleh Pak Bibit tadi di atas, mengatakan bahwa masa ini kehidupan tampak jauh lebih sulit dan masa Soeharto seolah memperlihatkan sebuah masa yang aman, tenteram, dan terkendali.

Mengesampingkan kontroversi seputar sosok Soeharto, tak memungkiri ia memang magnet yang besar untuk menarik kehadiran pengunjung museum. Pesonanya pun masih terlihat menjadi daya tarik pengunjung untuk berkunjung ke museum yang menghadirkan kisah mengenai Soeharto. Museum mencatat 
kedatangan pengunjung pada masa pembukaan dari bulan Maret 2013 hingga Desember 2013 telah mencapai jumlah kunjungan 43.058 orang (Sari, 2014: 61-62). Jumlah itu masih berlanjut hingga empat tahun setelah museum dibuka. Tak memungkiri setiap berkunjung ke museum tempat ini memang tak pernah sepi.

Museum ini boleh dibilang menghadirkan perkembangan museum yang jauh lebih kekinian yang disebut dengan new museology, tren serupa yang berkembang di Eropa. Museum berkembang menjadi tempat edukasi sekaligus wahana rekreasi untuk dikunjungi. Museum tak lagi dipandang sebagai sebuah tempat untuk menyimpan benda-benda antic belaka. Museum telah berkembang luas menjadi sebuah tempat yang inklusif bagi seluruh lapisan masyarakat seperti yang disebutkan oleh Peter van Mensch and Leontine van Mensch (2011) dalam bukunya yang berjudul, 'New Trend of Museology': “...contemporary museology calls for inclusive museums that are not only responsive and engaging, but most of all participatory..." (Van Mensch, 2011: 49).

Rumah tinggal lama Soeharto diubah menjadi bangunan yang lebih baru lagi dengan gaya arsitektur tradisional Jawa yakni berbentuk rumah joglo. Bangunan museum dipadukan dengan bentuk arsitektur modern pula untuk beberapa bangunan seperti musola. Ruang pamer museum menyediakan berbagai macam peralatan multimedia untuk mendukung sebuah partisipasi aktif pengunjung ketika melihat displai pameran. Dengan segala daya tarik inilah, Museum H.M. Soeharto dikunjungi oleh banyak orang, tak melulu pecintanya tetapi juga anak-anak kecil dan masyarakat yang tinggal di sekitar museum.

Dari penamaan yang disematkan pada bangunan ini yaitu: 'museum' dan 'memorial' memberikan dua makna ganda sekaligus terhadap bangunan yang didirikan ini. Memorial dalam Kamus Besar Bahasa Indonesia (2008) diartikan sebagai sesuatu yang dibuat (didirikan) sebagai peringatan peristiwa bersejarah atau sebagai peringatan seorang tokoh. Sementara itu, definisi mengenai museum sendiri berbeda dengan maknanya sekedar sebuah tugu peringatan.

Jika merujuk pada International Council of Museums (ICOM, museum didefinisikan sebagai:

"... a museum is a non-profit in the service of the society and its development, open to the public, which acquires, conserves, researches, communicates and exhibits the tangible and intangible heritage of humanity and its environment for purpose education, study and enjoyment..." (Devallees and Mairesse (ed.), 2009: 57).

Dari pengertian tersebut, ini berarti museum memiliki tujuan untuk mengedukasi pengunjung melalui pameran-pameran yang ditampilkan sehingga dapat memberikan pengetahuan dan informasi yang terkait mengenai sosok Soeharto serta buah pemikirannya. Tulisan ini berupaya memaknai bagaimana museum yang 
menghadirkan tokoh Soeharto dalam sebuah ide dan memproduksi pengetahunpengetahuan tertentu tentang Soeharto.

\section{KERANGKA PEMIKIRAN}

Museum merupakan tempat untuk menyajikan dan memamerkan obyek koleksi atau seorang sosok dalam penelitian ini yakni sosok Soeharto. Akan tetapi, Hall (1997) kemudian memperlihatkan sebuah diskursus museum dan merupakan sebuah sistem konsep representasi yakni produksi sebuah makna melalui bahasa merupakan diskursus dan foto. Hall menyatakan bahwa:

"... a museum does not deal solely with objects but, more importantly, with what we could call, for the moment, ideas - notions of what the world is, or should be...."

“...Museum do not simply issue objective descriptions or form logical assemblages; they generate representations and attribute value and meaning in line with certain perspectives or classificatory schemas which are historically specific..." (Hall, 1997: 160).

Visi misi dari museum ini yang menjadi penentu bagaimana cara museum bekerja untuk menghadirkan representasi sosok Soeharto, tak hanya dalam displai narasi pameran namun juga seluruh pernak-pernik atribut simbol yang berdiri di seluruh kompleks Museum H.M. Soeharto. Berbagai simbol dan atribut itulah yang kemudian menghadirkan museum sebagai sebuah teks yang dibaca untuk dimaknai keberadaannya.

Menurut Hall (1997), "...exhibition are discrete events which articulate objects, texts, visual representations, reconstructions, and sounds to create an intricate and bounded representational system..." Ini berarti, sebuah sistem representasi hadir untuk memberi pemaknaan terhadap sosok Soeharto lewat berbagi foto, arca, perangkat multimedia, diorama, objek koleksi hingga narasi displai pamerannya. Objek-objek material yang ada dalam kompleks Museum Memorial H.M. Soeharto bertindak sebagai penanda (signifier) untuk membuat sebuah mental representasi (mental representation) yang merupakan bagian dari petanda/tinanda (signified) (Hall, 1997: 153-208).

Pesan yang diproduksi dikomunikasikan lewat cara memamerkan koleksi museum dalam pameran mereka. Menurut, dkk (2012) Tipe koleksi dalam museum terbgi dalam dua tipe koleksi, yaitu:

\section{Koleksi Tiga Dimensi (Three-Dimensional Collection).}

Dalam hal ini yang dimaksud tipe koleksi tiga dimensi merupakan jenis koleksi seperti artefak, fosil hewan ataupun manusia, spesimen hewan yang telah diawetkan, hingga benda-benda etnografi. 


\section{Koleksi Dua Dimensi (Two-Dimensional Collection).}

Tipe koleksi dua dimensi ini mencakup koleksi arsip berupa rancang gambar, lukisan, berbagai macam foto, rekaman suara dan video. Arsip yang telah terdigitalisasi juga dianggap sebagai koleksi museum kategori ini. Buku ataupun surat kabar yang relevan dengan museum juga merupakan koleksi yang harus diurus oleh museum.

Barang-barang yang telah masuk ke dalam museum nantinya mengalami transformasi menjadi benda koleksi museum. Transformasi benda material tersebut ke dalam konteks museum disebut dengan musealisasi atau proses menjadikan suatu benda sebagai objek koleksi museum. Transformasi ini memiliki konsekuensi harus ditanggalkannya fungsi benda tersebut dari konteks sosial dan disesuaikan dengan makna dan tujuan dari museum itu berdiri. Benda material tercerabut asalnya. Benda tersebut menjadi entitas baru dan bergabung dengan koleksi-koleksi lain di museum menjadi sebuah identitas baru untuk menampilkan sebuah cerita yang disesuaikan dengan visi dan misi pendirian museum. Musealisasi ini tak lain upaya untuk memarjinalkan kenyataan karena benda berbicara dalam konteks yang telah disusun oleh kurator ketika membuat jalinan cerita dalam pameran museum mereka (Desvallees, Andre \& Francois Mairesse, 2009:50).

Pameran museum dan objek koleksi yang ada di museum hadir untuk sebuah bentuk pesan yang dapat dibaca oleh pengunjung. Timothy W. Luke menyatakan dalam bukunya Museum Politics: Power Plays at the Exhibition (2002):

"...it was power that constructed these truth, and such truths were meant to express, justify, and occlude the cultural, economic, and political power that enable it to operate in this manner. Believing that power should shape this institutionalized knowledge, and wanting that knowledge to math many-layered conceptions of this institutionalized power..." (Luke, 2002: xxiii)

Narasi dalam displai pameran, ditulis secara sengaja maupun secara implisit menyimpan pengetahuan tertentu untuk pengunjung. Narasi menghasilkan pengetahuan yang spesifik. Focault telah memberikan gambaran mengenai konsep kuasa pengetahuan bahwa kini kekuasaan tak lagi dilihat dengan cara yang kasar namun diciptakan sebagai sebuah realitas sehari-hari. Kuasa menghasilkan sebuah pengetahuan yang tak disadari oleh masyarakat. Pemilik kekuasaanlah yang melahirkan pengetahuan-pengetahuan baru tersebut. Pengetahuan itu dipertukarkan antar anggota suatu kebudayaan melalui simbol-simbol yang dihadirkan dalam sebuah pameran museum, untuk menghadirkan pengetahuan yang kemudian dianggap 'benar' (regim of truth) (Baker, 200:154; Hall, 1997: 49; Sarup, 2008: 112-113). 


\section{NARASI KEPAHLAWANAN SOEHARTO}

Museum Soeharto diresmikan pada tanggal 8 Juni 2013, 15 tahun setelah reformasi 1998 yang kemudian menggulingkan Soeharto sebagai presiden setelah 32 tahun berkuasa. Kompleks museum ini menempati bekas rumah lama Soeharto. Gagasan mendirikan museum ini berasal dari adik tiri Soeharto, yakni Probosutedjo. Peresmian museum ini dilakukan oleh Mbak Tutut (putri sulung Soeharto), Probosutedjo, dan beberapa pejabat negara yang saat itu menjabat seperti Agung Laksono dan Moh. Nuh.

Kompleks Museum Soeharto terdiri dari beberapa bangunan antara lain: pendopo, ruang pameran utama yang diberi nama Gedung Atmosudiro, ruang perpustakaan, bangunan sumur petilasan yang berada di bagian belakang kompleks museum dan sebuah Musholla tempat beribadah bagi umat muslim.

Bangunan pendopo biasa digunakan bagi pengunjung sebagai titik berkumpul. Pendopo merupakan bangunan tradisional dengan konstruksi kayu dengan empat tiang penyangga utama disebut dengan Soko, tanpa dinding sehingga tampak terbuka - dibangun tanpa tembok. Pendopo tersebut juga digunakan sebagai ruang terbuka yang bisa diakses oleh siapa saja tanpa perlu merasa segan. Perpustakaan museum ini tidak berada di dalam bangunan ndalem tersebut melainkan berada di bagian teras rumah. Rak dibuat memanjang, berisi puluhan judul buku yang kebanyakan berupa buku biografi Soeharto atau buku yang mengulas tentang sosok Soeharto dalam yang mengesankan Soeharto secara positif.

Di halaman museum tersebar patung-patung arca Soeharto. Arca besar menjulang tinggi memperlihatkan sosok Soeharto dalam balutan seragam militer lengkap. Pangkat kemiliterannya, ada lima bintang yang menunjukkan Soeharto memiliki gelar Jenderal Besar. Gelar jenderal besar itu merupakan bentuk sebuah gelar di luar kepangkatan karir militer TNI. Indonesia sendiri hanya memiliki tiga jenderal yang diberi anugerah Jenderal Besar, yaitu Jenderal Soedirman, Jenderal A.H. Nasution dan Jenderal Soeharto ini sendiri. Gelar Jenderal Besar Bintang Lima tidak lagi lazim diberikan. Di Amerika, gelar kehormatan ini diberikan hanya pada masa perang. ${ }^{\mathrm{i}}$

Patung lainnya berdiri di sebuah kolam ikan. Tampak patung dua bocah yang sedang bermain dengan seekor kerbau. Letaknya patung itu tepat di tengah kolam, ingin menggambarkan suasana masa kecil Soeharto yang terpotret pernah sedang menggembala kerbau dan bermain di sawah. Patung itu menjadi representasi Soeharto bocah yang memiliki kehidupan bersahaja ketika kecil. Sawah dan pertanian lekat sekali untuk menggambarkan Soeharto. Kehidupan bertani di waktu kecil menjadikan Soeharto memiliki obsesi besar pada bidang pertanian. Hingga termasuk 
menjadikan Indonesia sebagai negara swasembada beras pada tahun 1987 dan diakui oleh badan pangan dunia (FAO) (Abdulgani-Knapp, 2007: 23; 265).

Dua patung berikutnya berdiri mengapit bangunan ruang pameran utama dari museum ini. Patung yang berdiri di dekat pintu masuk ruang pamer dilekatkan pada dinding batu segi empat yang menampilkan tiga aksara Jawa 'Sa - Sa - Sa', yang kemudian diartikan sebagai sebuah nasehat dalam bahasa Jawa yaitu 'Sabar - Saleh Sareh'. Ketiganya 'sa' itu merupakan sebuah nasehat bijakasana yang berarti bahwa sebagai manusia kita harus selalu: Sabar Atine (selalu sabar) - Saleh Pikolahe (selalu saleh taat beragama) - Sareh Tumindake (selalu bijaksana)'. Di samping kata-kata mutiara itu, tampak sosok patung Soeharto dipahatkan dalam sikap tangan 'ngapurancang' atau dalam sikap tangan yang sopan dalam adat Jawa dengan sedikit menundukkan kepala. Berbeda dari patung yang sebelumnya yang tampil dalam seragam militernya, patung Soeharto ini digambarkan memakai peci sebagai penutup kepala, baju koko dan sebuah sarung. Sementara itu, patung yang berada di samping pintu keluar ruang pamer, memperlihatkan sosok Soeharto dalam posisi atahiyad terakhir, yaitu posisi duduk pada akhir ibadah sholat dalam agama Islam. Tak ada keterangan apapun pada patung Soeharto itu namun bisa terlihat bahwa sosok Soeharto digambarkan tampak sebagai sosok religius.

Berbagai artikel harian surat kabar yang dipasang pada bagian teras di bangunan ruang pameran utama juga memperlihatkan cerita-cerita Soeharto yang religius. Seperti berita tentang Soeharto yang menunaikan ibadah haji. Pernah dikemukakan oleh sejarawan Rifckles dalam bukunya yang berjudul 'Mengislamkan Jawa' (2012), sosok Soeharto banyak diragukan identias keislamannya oleh beberapa pemimpin-pemimpin organisasi Islam. Kesukaan Soeharto pada mistikisme dan Islam yang lebih abangan banyak membuatnya dipertanyakan. Selain itu pula, sejarah juga memperlihatkan usaha-usaha Soeharto untuk membuat organisasi Islam lebih 'jinak' dengan mendirikan banyak lembaga negara, sepeti MUI ataupun di bidang pendidikan pendirian IAIN memperlihatkan negara ingin menancapkan kukunya dalam-dalam agar dapat mengontrol kelompok organisasi Islami yang memperlihatkan kepimpinannya menjadi rezim totaliterian yang berupaya menjadikan Indonesia hanya memiliki satu paham ideologi semata (Ricklefs, 2012: $270-271 ; 374)$.

Jejak-jejak itu, mencoba ditangkis dengan berbagai patung Soeharto yang memperlihatnya tampak sedang duduk sujud melakukan Sholat sebagai bukti identitas keislamannya. Tak hanya itu saja, bangunan Mushola yang berdiri tampak mencolok di halaman depan bisa menjadi representasi diri Soeharto yang ingin dibangun. Bila, mushola biasanya dibangun sebagai fasilitas publik yang dibangun tersembunyi, seperti halnya di pusat-pusat perbelanjaan atau taman bermain, maka 
Mushola menjadi bangunan yang paling mencolok terlihat begitu kita memasuki halaman kompleks museum ini.

Meski demikian, atribut-atribut keislaman itu tak lepas dari Soeharto yang seorang Jawa. Patung Soeharto tetap melekat pada kata-kata filosofis Jawa mengenai sabar, sareh, dan soleh seseorang. Keduanya simbol ini menjadikan representasi Soeharto seorang abangan begitu kuat. Terlebih, dibangunnya bagian belakang museum, bangunan yang dahulu merupakan sumur - tempat mandi Soeharto kecil, dipercantik menjadi bangunan pendopo tempat petilasan. Menempati ruang di paling belakang, petilasan ini justru memperlihatkan religiusitas Soeharto hadir sebagai seorang yang beridentitas Islam namun masih tetap memegang kepercayaan terhadap ajaran-ajaran Jawa yang lebih filosofis terutama berkaitan tentang ketuhanan. Hanya saja, menempatkan Mushola di bagian paling muka sementara di belakang aspek Jawa dalam dirinya begitu kental memperlihatkan diri Soeharto tak hanya ingin dikenal sebagai seorang Islam saja.

Sementara itu ruang pameran di Gedung Atmosudiro merupakan representasi sosok Soeharto sebagai bagian dari militer. Pameran di Museum Soeharto terdiri dari lima bagian (sequences) cerita yang berpusat pada tokoh Soeharto, yaitu:
a. Pengenalan memorial.
b. Serangan Umum 1 Maret 1949
c. Operasi Trikora
d. Pemberontakan G30S/PKI
e. Repelita dan Hasil Pembangunan

Pemilihan cerita atau peristiwa sejarah yang diambil dalam museum tersebut mengingatkan saya pada beberapa museum-museum sejarah pejuangan yang telah terlebih dahulu ada. Kisah peperangan kerap diangkat di dalam museum-museum yang khusus bercerita mengenai perjuangan bangsa, seperti Museum Monumen Jogja Kembali yang mengangkat kisah peristiwa Serangan Umum Satu Maret (yang dalam museum ini juga dibsahas) lalu museum-museum militer TNI AD atau TNI AU yang masing-masing kerap menghadirkan kisah mengenai perisitwa Gerakan 30 September.

Pada masa Soeharto menjabat sebagai presiden ia memberlakukan standarisasi terhadap museum-museum daerah di seluruh provinsi Indonesia. Kebijakan top down untuk merancang landasan bahwa setiap museum harus menghadirkan kebudayaan Indonesia dan kisah sejarah yang homogen dan 'diakui' oleh pemerintah Orde Baru pada saat itu (Sudarmaji, 2004: 243). Storyline yang diangkat dalam pameran ini merupakan peristiwa-peristiwa yang kerap diulang-ulang dalam buku sejarah dan diajarkan semenjak sekolah dasar hingga tamat sekolah menengah atas. Dan tentunya kisah peristiwa yang dipilih oeh museum ini paling menonjolkan Soeharto. 
Museum Soeharto juga memberikan warna tersendiri karena museum ini tak memiliki koleksi obyek tiga dimensi untuk ditampilkan. Pameran museum yang ada hadir dalam gambar-gambar hasil reproduksi yang ditata sedemikian rupa. Sumber koleksi ini berasal dari arsip-arsip dan foto-foto lama Arsip Nasional.

Selasar Serangan Umum Satu Maret merupakan bagian cerita pertama yang diangkat dan menjadi mitos yang dibangun oleh Soeharto selama berkuasa. Sejak peristiwa ini, namanya mulai dikenal oleh masyarakat dan para petinggi negara. Cerita berikutnya yang diangkat yakni Trikora (Tri Komando Rakyat), akan tetapi kisah selasar ini lebih mengangkat pada pertempuran militer yang dipimpin oleh Soeharto untuk merebut Irian Barat dari Belanda. Di sini karir militer Soeharto mulai merangkak naik dan menjadi sosok cukup memiliki peran kenegaraan. Hal ini juga terbukti dari gambar-gambar foto hitam yang hadir sebagai koleksi museum memperlihat gambar Soeharto tampak sudah dibidik oleh mata kamera.

Setelah selasar Trikora, cerita digiring masuk ke dalam sekuen mengenai Gerakan 30 September. Peristiwa ini juga membuat sosok Soeharto menjadi kontroversional karena sejarah gelap yang mengiringi perpindahan kepemimpinan Orde Lama ke Orde Baru dimulai akibat pembunuhan tujuh orang terhadap elit militer AD di tahun 1965 itu. Selasar ini juga dibuat khusus untuk menceritakan sepak terjang Soeharto dalam perisitiwa ini hingga akhirnya ia diangkat menjadi presiden kedua RI. Kisah selasar ini mendapatkan porsi bercerita paling panjang dibandingkan dengan yang lainnya. Sama seperti horor dalam sejarah yang selalu diceritakan dalam buku-buku sejarah, selasar ini juga nampak lebih suram dibandingkan yang lainnya. Di sini pula terdapat foto-foto sadis korban pembunuhan di Lubang Buaya. Foto hitam putih tersebut hadir tanpa sensor atau pun dikaburkan, tampak mentah menampilkan sejarah yang kelam.

Selasar terakhir berkisah mengenai prestasi yang didapatkan oleh Soeharto sepanjang 32 tahun ia memimpin. Pencapaian pembangunan Indonesia terpampang dalam foto-foto yang lebih berwarna menunjukkan kemajuan bangsa Indonesia karena percepatan pertumbuhan perekonomian. Selasar ini juga menunjukkan corak khas rezim Orde Baru dalam menjalankan pemerintahan yang berorientasi terhadap pembangunan dan kebijakan sentralistik. Akhir selasar juga menceritakan kejatuhan Soeharto dari jabatannya. Pada akhirnya diceritakan pula mengenai pemakaman Soeharto yang dihadiri oleh ribuan orang untuk menunjukkan kebesaran nama Soeharto.

Dalam setiap penulsian-penulisan biografi, terdapat empat unsur yang sekiranya wajib hadir yaitu (1) kepribadian tokoh, (2) kekuatan sosial yang mendukung, (3) lukisan sejarah zamannya, dan (4) keberuntungan dan kesempatan yang datang (Kuntowijoyo, 2003: 204-205). Sebagai sebuah produk museum yang khusus menghadirkan biografi tokoh, selayaknya pakem penulisan riwayat hidup, 
maka cerita-cerita Soeharto yang hadir tampak menyajikan nuansa kepahlawan yang menonjol. Sesuai dengan visi dan misinya, pendirian Museum H.M. Soeharto ini merupakan tempat untuk mengenang nilai-nilai perjuangannya sebagai sumber inspirasi bagi penerus bangsa. Penulisan biografi yang menganut hero in history akan menghadirkan naratif yang menonjolkan sifat-sifat tertentu yang menempatkan diri mereka sebagai sosok pahlawan (Kuntowijoyo, 2003).

Sidney Hook mengungkapkan beberapa konsep kepahlawaan dalam bukunya yang berjudul Hero in History (1992), antara lainnya adalah hal yang mendasar dari sosok pahlawan ialah sikap kepemimpinan yang dimiliki oleh tokoh tersebut. Kharisma untuk memimpin itu menjadi faktor penggerak utama bagi masyarakat untuk menghormati sang pahlawan. Meski pun demikian, tak hanya berhenti dalam kharisma kepemimpinan semata.

Ada beberapa aspek yang serupa dalam orang Jawa memandang sosok yang dianggap sebagai pahlawan. Orang Jawa memberikan sebutan pahlawan kepada sosok yang dinamakan Ratu Adil. Sosok ini merupakan tokoh yang muncul pada Ramalan Jayabaya. Ramalan Jayabaya ini mengatakan bahwa pulau Jawa akan mengalami masa kekacauan. Disitulah kemudian Sang Ratu Adil Herucakra yang akan mengembalikan kembali ketenteraman pulau Jawa. Dongeng mengenai Ratu Adil ini begitu dipercayai orang Jawa. Kisah Ratu Adil ini pun juga digunakan oleh Pangeran Diponegoro untuk melakukan pemberontakan terhadap orang Belanda yang kemudian berbuntut terjadinya Perang Jawa tahun 1825-1830. Diponegoro bergerak atas Ramalan Jayabaya yang menyebutkan kemunculan Ratu Adil untuk memperbaiki kondisi pulau Jawa yang kacau ditangan Belanda (Magnis-Suseno, 1984).

Sosok Ratu Adil merupakan pandangan orang Jawa dalam melihat sosok yang ideal yang dianggap sebagai seorang pahlawan yang hadir untuk mengendalikan situasi kacau yang disebut oleh orang Jawa sebagai zaman edan. Kondisi yang disebut dengan zaman edan ialah masa ketika kekacauan terjadi akibat tidak ada kerukunan dan keharmonisan sebagai refleksi ketidakseimbangan antara manusia dengan jagad raya ini (Mulder, 1978: 14). Untuk menjadi sosok yang ideal tersebut dibutuhkan perjalanan spiritual yang panjang untuk mendapatkan kuasa yang mengantarkan seseorang menjadi sosok yang dianggap ideal sebagai pahlawan. Spiritualitas orang Jawa mengenal akan konsep kosmologi antara jagad gede (makrokosmos) dan jagad cilik (mikrokosmos). Alam semesta ini dipandang sebagai sebuah makrokosmos dan manusia merupakan refleksi dari alam semesta tersebut (mikrokosmos). Manusia yang berhasil menyeimbangkan dirinya dengan alam semesta ini kemudian dianggap telah menaklukkan hawa nafsu yang melingkupi dirinya. Ia bisa menyelaraskan lahir dan batinnya (Mulder, 1978: 13). Laku spiritual yang dilakukan oleh orang Jawa untuk mendapatkan kekuatan spiritual ini bisa didapatkan melalui semedi di tempat-tempat 
yang dipercaya mampu memiliki kekuatan supranatural, puasa, hingga menyepi ke makam leluhur.

Kekuatan yang didapat bagi orang-orang yang menjalankan praktek mistisisme Jawa ini justru tidak mengantarkan orang Jawa menjadi sosok yang kasar. Bagi orang Jawa, orang yang dipandang memiliki kharisma justru didapatkan dari laku halus. Bagi orang Jawa, kuasa (power) dipandang sebagai sesuatu yang halus. Oleh karena itu, orang yang hebat dipandang sebagai sosok yang halus. Kuasa orang Jawa bukanlah kekuasaan yang didapatkan dengan cara-cara yang keras. Sosok ideal bagi orang Jawa ialah orang halus, berbicara dengan tutur kata halus tapi mampu menggerakkan seluruh masyarakat. Sosok pemimpin juga diharapkan memiliki kualitas diri untuk menggerakkan masyarakatnya dalam sebuah keharmonisan. Sama seperti sosok pahlawan yang digambarkan oleh Ratu Adil sebelumnya, pemimpin yang baik harus membawa keharmonisan dalam kehidupan bermasyarakat. Pemimpin yang baik ialah yang mampu menyatukan seluruh masyarakat menjadi sebuah satu kesatuan (unity) tatanan yang harmonis. Individu bukanlah aspek penting dalam pandangan masyarakat Jawa. Nilai-nilai individiualitas tidaklah penting dalam masyarakat jika ia dianggap tidak bisa membaur dengan orang lain. Hal ini dikarenakan kebersamaan merupakan salah satu refleksi nilai keseimbangan yang didapat ketika manusia Jawa telah menyatukan diri dengan jagad raya (Anderson, 2007; Mulder, 1978: 41-43; Mulder, 2000: 40-42).

Hal ini yang juga mengantarkan kita pada sosok ideal pahlawan bagi bangsa Indonesia. Pemberian gelar pahlawan nasional oleh negara juga memiliki tata cara penilaian tersendiri. Pada masa Orde Baru, pengaturan pemberian gelar pahlawan nasional tak bisa sembarangan diberikan. Pemerintah Soeharto menerbitkan buku dalam lima seri berjudul Wajah dan Sejarah Perjuangan Pahlawan Nasional (1994-1995) yang menceritakan profil pahlawan, baik laki-laki maupun perempuan, yang layak mendapatkan gelar pahlawan nasional ini. Mereka yang disebut dengan pahlawan ialah para pejuang yang telah mengorbankan diri mereka untuk menjaga keutuhan dan kedamaian di NKRI. Stereotip pahlawan diberikan kepada orang-orang yang telah meninggal atau gugur untuk menjaga keutuhan Republik Indonesia. Mereka yang telah gugur dianggap sebagai sosok pahlawan mengantarkan Indonesia menuju bangsa yang modern dan maju. Tak lupa menyebutkan bahwa modernitas dan kemajuan yang dicapai oleh bangsa merupakan salah ambisi besar Orde Baru dan dianggap sebagai masa keemasan pemerintah Indonesia karena berhasil mewujudkan pembangunan, kemakmuran, dan kesejahteraan berkat kemajuan ekonomi telah berhasil dicapai oleh Soeharto pada masa pemerintahannya (Wood, 2005: 31-32)

Kriteria pemberian gelar kepahlawanan kini pun tak jauh berbeda dengan aspek-aspek yang telah dilukiskan oleh pemerintah Orde Baru. Negara dalam hal ini pemerintah telah mengatur pemberian gelar kepahlawanan dan tanda jasa lewat 
Undang-Undang No. 20 Tahun 2009. Pemberian gelar kepahlawanan diberikan kepada sosok yang berjasa terhadap bangsa dan negara. Lebih khusus lagi, pemberian gelar pahlawan nasional diberikan kepada orang yang telah meninggal/gugur demi membela negara dan bangsa Indonesia dalam melawan penjajah maupun sosok yang melakukan tindakan kepahlawan atau menghasilkan kontribusi yang besar terhadap kemajuan Indonesia ${ }^{1}$.

Berbagai kriteria mengenai aspek kepahlawanan ini yang menjadi landasan bagi negara atau masyarakat menganggap seorang tokoh sebagai sosok pahlawan. Sidney Hook (1992) telah mengungkapkan, "...Whoever saves us is a hero and in the exigences of political action men are always looking for someone to save them..." (Hook, 1992: 1-6). Jadi, sosok pahlawan ialah sosok yang mampu menyelamatkan situasi dan kondisi kacau yang nampaknya tak memiliki jalan keluar. Pahlawan ialah sosok yang memberikan solusi, mampu menghadirkan kedamaian di muka bumi ini kekuatannya seperti halnya konsep Ratu Adil akan menyelamatkan kita semua dari kekacauan zaman. Munculnya sosok pahlawan tentunya tak bisa lepas dari sosok yang dijadikan antagonis sehingga sekali lagi kharismanya sebagai pemimpin dan pahlawan akan semakin cemerlang (Hook, 1992: 1-6; Klapp, 1948:135).

Dalam pembuatan narasi cerita kepahlawanan, terutama yang berkaitan mengenai militerisme dan peperangan, amat sangatlah mudah membungkus sebuah cerita tersebut dengan menghadirkan tokoh protagonis dan antagonis. Setiap peperangan tentu saja memiliki musuh besar yang harus dihadapi untuk mencapai kemerdekaan. Narasi dalam Museum Soeharto menghadirkan sebuah cerita kepahlawanan dengan menampilkan berbagai 'musuh' yang dihadapi oleh Soeharto dalam perjalanan hidupnya.

Pemerintahan Hindia-Belanda merupakan sosok antagonis yang menjadi penjajah bangsa Indonesia. Dongeng penjajahan Indonesia yang dilakukan oleh Belanda telah diwariskan dari generasi ke generasi. Kisah kepahlawanan Soeharto diceritakan sebagai sebuah kisah perjuangan untuk mencapai kemerdekaan bangsa melalui perang. Soeharto digambarkan sebagai pahlawan yang telah berkontribusi untuk mendapatkan kemerdekaan seutuhnya melalui kisah pada di Selasar Serangan Umum Satu Maret dan Selasar Operasi Mandala. Musuh nyata yang ada pada kisah kepahlawanan Soeharto jelas jatuh pada Belanda yang pada saat itu tampak hendak

\footnotetext{
${ }^{1}$ UU No. 20 Tahun 2009 Pasal 1 Ayat 4. Pahlawan Nasional adalah gelar yang diberikan kepada warga negara Indonesia atau seseorang yang berjuang melawan penjajahan di wilayah yang sekarang menjadi wilayah Negara Kesatuan Republik Indonesia yang gugur atau meninggal dunia demi membela bangsa dan negara, atau yang semasa hidupnya melakukan tindakan kepahlawanan atau menghasilkan prestasi dan karya yang luar biasa bagi pembangunan dan kemajuan bangsa dan negara Republik Indonesia. Lihat http://www.bpkp.go.id/uu/file/2/26.bpkp diunduh tanggal 27 Agustus 2016 pukul : 17:39 WIB.
} 
menginginkan kembali merebut NKRI. Soeharto pun dilukiskan berhasil mencapai kemenangan sehingga musuh bangsa tersebut kalah dan mundur angkat kaki dari negara ini.

Musuh bangsa yang digambarkan berikutnya oleh Soeharto ialah PKI. Selasar ini tentunya mendapatkan perhatian khusus oleh pengelola museum sehingga memuat informasi yang paling kaya dan panjang mengenai peristiwa pembunuhan enam jenderal TNI AD dan satu orang ajudan. Suasana selasar yang dibuat mencekam dengan gambar-gambar hitam putih tanpa sensor merepresentasikan masa gelap dari bangsa Indonesia. Pada akhirnya, narasi pun menampilkan Soeharto sebagai pahlawan yang telah menyelamatkan bangsa Indonesia dari ancamanan komunis yang dianggap sebagai kejahatan berat terhadap negara. Bila tidak ada Soeharto, maka arah masa depan bangsa tak akan jelas ke mana.

Berbagai musuh yang dihadapi semenjak narasi di Selasar Serangan Umum Satu Maret menuntun pengunjung untuk melihat bahwa hilangnya musuh-musuh yang mengancam bangsa membawa kita pada masa kedamaian dan kemakmuran yang direpresentasikan pada selasar paling akhir. Selasar pembangunan menunjukkan berbagai keberhasilan Soeharto selama 32 tahun memerintah di Indonesia. Selasar ini tampak cerah dan menampilkan betapa idealnya bangsa Indonesia ketika Soeharto menjabat sebagai presiden. Gemah ripah loh jinawi atau pepatah Jawa yang memberikan gambaran kekayaan alam di Indonesia serta kesuburan tanah yang memberikan kemakmuran. Pemimpin yang berhasil menyatukan Indonesia dalam sebuah kesatuan layak menjadi seorang pahlawan yang didamba-dambakan oleh seluruh rakyatnya. Berbagai keberhasilan dalam bidang pembangunan dipamerkan dalam displai Museum Soeharto sebagai sebuah pengingat bahwa Soeharto mampu membawa Indonesia pada masa-masa yang sejahtera tanpa konflik. Soeharto dianggap sebagai refleksi dari raja yang berhasil membawa keseimbangan dunia jagad raya dan kosmik sehingga kemakmuran yang dicapai pada masa pemerintahannya bukan hal yang mengherankan. Ia adalah gambaran Ratu Adil yang berhasil membawa Indonesia yang tampak harmonis meskipun dibalik usahanya untuk memperlihatkan kondisi yang stabil pemerintahan Order Baru bekerja dengan begitu represif terhadap orangorang yang dianggap 'mengacaukan' tatanan kerukunan tersebut.

Kisah Soeharto di dalam museum hanya diceritakan sampai pada akhir kepemimpinannya pada bulan Mei 1998, sebelum akhirnya ia mengundurkan diri dari jabatan presiden yang kemudian mengawali era reformasi. Sosok Soeharto pun lenyap di antara riuhnya suara reformasi di Indonesia. Akhir kisah perjalanan hidup Soeharto ditutup dengan gambar arak-arakan yang mengiringi jenazah menuju liang lahat. Cerita perjalanan Soeharto yang dikisah pada displai pamer museum tak memperlihat perjalanan Soeharto pasca-reformasi. 
Soeharto pasca-reformasi bukanlah menjadi tokoh favorit orang-orang. Kepahlawaan Soeharto tenggelam seiring dengan banyaknya memberitakan mengenai Soeharto dan tuduhan-tuduhan hukum yang dituduhkan padanya. Dalam semalam ia berubah menjadi tokoh antagonis. Berbagai tundingan dijatuhkan kepada Soeharto dan dia dianggap bertangungjawab atas berbagai peristiwa kontroversial, seperti peristiwa pembantaian simpatisan PKI pasca-G30 S, pembunuhan petrus, kerusuhan di Tanjung Priok pada tahun 1984, dan tuduhan atas KKN yang dilakukan melibatkan yayasan-yayasan yang didirikan oleh Soeharto (Abdulgani-Knapp, 2007:222).

Atas berbagai kasus dugaan korupsi dan nepotisme yang dilakukan oleh Soeharto pada saat ketika ia menjabat sebagai presiden, mantan presiden itu kemudian diperkarakan di pengadilan. Berbagai panggilan untuk memberikan keterangan dan kesaksian telah membuat kesehatan Soeharto menurun drastis. Ia menderita pendarahan di bagian alat pencernaan, berulang kali mengalami serangan jantung, stroke, dan berbagai penyakit yang muncul sehingga membuatnya tak mampu menjalani persidangan. Ia menjadi tua dan ringkih. Kehilangan kekuasaan dan perlahan menghilang dari pusaran pemberitaan. Soeharto tampak pelan-pelan menghilang dan menyepi. Segala tuntutan yang diganjarkan padanya bisa dihindari dengan alasan kesehatannya yang rentan tersebut. Saat pemakaman Soeharto, banyak pejabat negara yang tampak hadir melayat. Presiden Indonesia saat itu, Susilo Bambang Yudono pun turut hadir mengantar jenazah dan memberikan penghormatan terakhir kepada jenderal besar itu. Ia mengatakan Indonesia telah kehilangan salah satu putra bangsa yang memberikan kontribusi terhadap pembangunan Indonesia. Sikap tersebut menjadi cerminan bahwa publik bersikap ambigu terhadap persoalan Soeharto (Aspinall et al, 2010: 3; Abdulgani-Knapp, 2007: 285-290).

Tuntutan publik terhadap penyelesaian kasus Soeharto pun tak lagi setinggi dahulu. Hal ini menyebabkan sosok Soeharto perlahan menjadi sosok hantu di masa lalu. Rentang masa reformasi yang telah berlalu sekitar 18 tahun lalu perlahan memudarkan ingatan. Hampir satu dekade lebih Indonesia mendefinisikan reformasi. Harga yang sangat mahal telah dibayarkan untuk memulai sebuah pemerintahan baru yang lebih bersih dan terbuka. Berbagai peristiwa telah menimpa Indonesia pascareformasi, seperti pergantian kepemimpinan, pencarian embrio demokrasi yang ideal untuk ditetapkan di Indonesia, dan berbagai perubahan sosial dalam masyarakat Indonesia secara keseluruhan.

Perubahan ini tampak sebagai sebuah perubahan yang tampak mengkhawatirkan masyarakat karena mereka ditempatkan dalam situasi yang penuh kebingungan karena berbagai upaya yang dilakukan oleh pemimpin baru tampaknya selalu gagal menghasilkan kebijakan baru yang memberikan kesejahteraan terhadap mereka. Harga barang pokok semakin meroket dan masyarakat tampak semakin 
miskin. Masyarakat tak lagi sejalan dengan banyaknya pemberitaan mengenai kerusuhan antar kelompok dan golongan yang terjadi di mana-mana.

Era reformasi yang diharapkan memberi perubahan pada iklim politik di Indonesia supaya menjadi lebih terbuka tampaknya tak berjalan lancar. Hingga hari ini kita masih kerap menemui warisan Orde Baru melalui praktik korupsi yang marak terjadi di lembaga negara, premanisme yang terjadi antar para elit atau kelompok yang dominan, dan sifat-sifat represif dari negara lainnya yang menunjukkan gejala bahwa reformasi 98 telah gagal (Aspinall, 2010: 3).

Kondisi yang tampak kacau ini telah menyeret Indonesia kembali pada situasi yang disebut oleh orang Jawa sebagai zaman edan. Masyarakat kembali lagi mengalami situasi yang tak menentu. Perubahan budaya, globalisasi, konflik kepentingan, serta perubahan teknologi yang semakin maju membuat perubahan tatanan masyarakat kini bergerak menuju ketidakteraturan. Tatanan masyarakat ideal tentu saja terletak pada pemahaman bahwa masyarakat harus dapat menempatkan diri mereka sesuai dengan fungsi dan statusnya. Masyarakat harus dapat kembali menghormati hierarki dan harmoni yang ada (Mulder, 1978: 102-103).

Situasi semacam ini tentu saja memunculkan kembali nostalgia akan masa lalu terhadap masa-masa yang menunjukkan Indonesia yang tampak teratur dan sejahtera. Soeharto perlahan menjadi sosok yang ambigu, dicintai sekaligus dibenci. Nostalgia terhadap kepemimpinan Soeharto yang dianggap memberikan kesejahteraan terhadap Indonesia bermunculan sebagai pengunjung museum yang tampak hadir untuk mengenang kembali masa-masa tersebut.

Kegagalan reformasi juga menjadi salah satu jalan untuk mengangkat kembali narasi Soeharto ke publik melalui pembangunan museum ini. Menurut Najib Asca, sosiolog dari Universitas Gadjah Mada, pembangunan pusat informasi mengenai Soeharto merupakan tindakan rasional yang dilakukan untuk mengembali citra dari dinasti politik keluarga Soeharto. Sosok yang sempat menjadi tokoh antagonis pada masa awal reformasi, kembali hidup melalui displai-displai pamer di Museum Soeharto sebagai tokoh nasional yang seharusnya mendapatkan tempat yang layak.

Usaha pengembalian citra Soeharto tersebut sejalan dengan usaha untuk menciptakan ulang sosok Soeharto sebagai pahlawan setelah sosok ini terpuruk menjadi tokoh antagonis. Akan tetapi, penciptaan-ulang kepahlawaan Soeharto ini menanggalkan fakta-fakta obyektif yang ditampilkan dalam produk industri sejarah yaitu Museum Memorial H.M. Soeharto ini. Proses penciptaan pahlawan atau disebut sebagai heroification. James W. Loewen menyebutkan heroification ialah “... a degenaritve process (much like calcifiation) that makes people over into heroes. Through this process, our educational media turn flesh-and-blood individuals into pious, perfect creatures without conflicts, pain, credibility, or human interest..." (Loewen, 1995: 9). 
Proses menciptakan sosok pahlawan akan melepaskan realitas-realitas yang dianggap sebagai aib bagi tokoh yang bersangkutan. Produk industri sejarah, seperti monumen, memorial, buku-buku teks pelajaran, kebanyakan ditujukan untuk generasi yang lebih muda. Pahlawan ditampilkan dalam narasi yang menggambarkan sosok tersebut begitu patriotik dan digambarkan sebagai sosok yang baik karena kontribusinya sebagai pejuang. Terlebih lagi, kita seolah dituntut untuk berbicara dalam kalimat yang pantas untuk membicarakan tokoh yang telah meninggal (Loewen, 1995: 24-25). Hal ini sejalan dengan landasan pengelola museum ketika mendirikan museum untuk mengenang Soeharto ini dengan falsafah Jawa yakni 'Mikul Dhuwur Mendhem Ngisor'.

"Jadi yang menggagas berdirinya museum ini ialah adik beliau (Soeharto) yaitu Pak Probo (Probo Sutedjo). Namanya Bapak Haji Probosutedjo. Pak Probo ini belajar falsafah Jawa dari kakaknya. Jadi konsep yang diingat oleh Pak Probo dari Pak Harto ini yakni 'Mikul Dhuwur Mendhem Jero', maknanya Mikul Dhuwur Mendhem jero ini, bagaimana seorang anak dan seorang adik peduli dengan pendahulunya. Apa-apa yang baik yang dapat menjadi contoh bagi orang lain harus ditunjukkan (pikul ndhuwur), dan mendhem njero itu hal-hal negatifbisa disimpan se-dalam-dalamnya..." (Gatot Nugroho, 49 tahun)

Museum Soeharto hadir sebagai sebuah salah satu produk sejarah untuk merekonstruksi kembali kepahlawanan Soeharto. Penciptaan-ulang kepahlawanan Soeharto tampaknya belakangan juga kembali bergaung dengan wacana usaha pemberian gelar 'Pahlawan Nasional' kepada Soeharto yang diajukan oleh Partai Golkar dalam Musyrawarah Nasional Luar Biasa pada bulan Mei 2016 yang lalu. Keinginan untuk memberikan gelar 'Pahlawan Nasional' saat ini kepada Soeharto tampaknya memperlihatkan keberadaannya sosok yang perlahan beranjak dari citra antagonis.

Pun masyarakat diajak melakukan pencarian Ratu Adil di tengah-tengah situasi zaman edan seperti saat ini. Melalui berbagai gimmick 'Piye Kabar'e? Penak Jamanku to?' yang bermunculan dan pendirian museum sekaligus monumen ini, masyarakat diajak untuk bernostalgia untuk berangan-angan akan masa ketika Indonesia begitu harmonis dan teratur. Musuh yang hendak ditampilkan bukan lagi berasal dari negara penjajah ataupun ideologi bangsa yang terancam karena komunisme, melainkan situasi Indonesia yang dianggap gagal menghadirkan keteraturan dan keharmonisan pasca-reformasi.

\section{KESIMPULAN}

Mikul Dhuwur Mendhem Njero menjadi sebuah pepatah bahasa Jawa yang dipakai oleh museum ini untuk menghadirkan Soeharto dalam sebuah pameran 
museum. Tanggung jawab generasi yang lebih muda harus menyimpan rapat-rapat keburukan orang tua dan menampilkan sisi terbaiknya saja. Itu pula yang menjadi pijakan museum ini dalam bercerita. Representasi Soeharto dihadirkan kembali sebagai sosok yang religius, penganut budaya Jawa kental, seorang pahlawan yang telah kembali hadir melalui sosok militer yang gagah. Berbagai pernak-pernik fisik yang hadir terhampar di seluruh kompleks museum bekerja untuk menghadirkan representasi Soeharto tersebut. Representasi secara simbolik tersebut telah menjadi gagasan mengenai Soeharto bagi siapa saja yang pernah hidup dan tinggal di Indonesia ketika rezim Orde Baru berlangsung selama 32 tahun. Gagasan mengenai Soeharto yang kini terus awet diwariskan dalam narasi-narasi panjang dan kisah sejarah yang dulu pernah menjadi produk tunggangan politik Soeharto ketika masih berkuasa.

Museum Soeharto merupakan terobosan produk sejarah mengenai Soeharto dan Orde Baru yang dibangun 15 tahun pascareformasi. Tentu saja menjadi hal yang menggelitik bagi penulis untuk mengetahui bagaimana cara bercerita keluarga mengenai sang Bapak dalam museum ini setelah rentang waktu yang cukup panjang bagi masyarakat Indonesia perlahan melihat sosok Soeharto tak lagi sebagai sosok antagonis. Wacana-wacana Orde Baru hadir tanpa perlu repot-repot untuk membuat sebuah narasi yang lebih berimbang sehingga Soeharto sebagai simbol Orde Baru tampil tanpa cela. Museum ini layaknya dibuat sebagai sebuah tugu peringatan bagi orang yang mati, dihadirkan dalam nada positif untuk melayani kepentingan orang yang masih hidup atau keluarga yang ditinggalkan. Keinginan keluarga menghadirkan kebaikan sang pemimpin dan mengubur dalam-dalam segala keburukannya menjadi cara bagi keluarga yang ditinggalkan untuk melepas citra buruk yang melekat tak hanya terhadap orang tua namun juga stigma yang melekat terhadap mereka selama ini sebagai bagian dari sebuah keluarga pemimpin rezim Orde Baru.

Boleh jadi, museum juga dapat dipakai sebagai tunggangan untuk kepentingan politik anak-anak Soeharto. Sang Bapak yang telah mewariskan cerita kisahnya kini dimanfaatkan oleh anak-anak untuk mendapatkan dukungan masyarakat yang dahulu pernah mencintai Soeharto dengan sepenuh hatinya. Dengan memanfaatkan warisan nama besarnya, pengelola museum-yang kemudian menempatkan diri sebagai 'anak-anak' dari sang bapak, tak segan untuk menggunakan namanya sebagai magnet penarik bagi para pemujanya. Pengelola museum menggunakan kesempatan ini untuk mengeksploitasi kembali figur Soeharto untuk melanggengkan power yang pernah dimiliki oleh Keluarga Cendana dan orang-orang yang di sekelilingnya. Lihat saja yang pernah dilakukan oleh Titi Prabowo pada kampanye politik tahun 2014 lalu, dan boleh jadi akan diulang kembali di tahun 2019 ini. 
Upaya Museum Soeharto juga tampak untuk membuka sosok Soeharto yang ketika memimpin tampak begitu angker sulit didekati dengan membuat sebuah ruang publik yang terjangkau dan mudah diakses oleh seluruh lapisan masyarakat. Suguhan foto-foto keluarga yang dahulu tak mungkin diakses oleh orang biasa juga ditampilkan dengan leluasa. Bahkan rumah keluarga Soeharto di jalan Cendana juga ditampilkan untuk menarik pengunjung yang penasaran dengan rumah tinggal bekas presiden RI tersebut yang dahulu ketika Orde Baru tampak begitu sulit untuk ditembus. Dengan membuka lapis demi lapis kehidupan Soeharto sosok tersebut dianggap jauh lebih terasa dekat dengan dan tampak terjangkau oleh masyarakat umumnya. Tulisan ini bertujuan menjadi sebuah karya yang reflektif untuk melihat bagaimana kondisi Indonesia pascarreformasi. Warisan Orde Baru telah menjadi sebuah warisan yang telah mengakar dalam tatanan masyarakat hingga hari ini tanpa disadari, salah satunya melalui sebuah institusi yang bernama museum ini.

\section{DAFTAR PUSTAKA}

Buku dan Artikel

Abdulgani-Knapp, Retnowati. 2007. Soeharto: The Life and Legacy of Indonesia's Second President. Singapore: Marshall Cavendish Editions.

Anderson, Benedict. 2007. The Idea of Power in Javanese Culture dalam buku Culture and Politics in Indonesia (ed) Claire Holt. Jakarta: Equinox Publishing

Aspinall, Edward \& Greg Fealy. 2010. Introduction: Soeharto's New Order and its Legacy dalam Soeharto's New Order and its Legacy: Essay in Honour of Harold Crouch (ed) Edward Aspinall \& Greg Fealy. Australia: ANU E Press. Diunduh http://epress.anu.edu.au/soeharto_citation.html

Barker, Chris. 2004. Cultural Studies: Teori \& Praktik. Yogyakarta: Kreasi Warna

Desvallees, Andre \& Francois Mairesse (ed). 2009. Key Concepts of Museology. Perancis: Armand Colin

Hall, Stuart (ed). 1997. Representation: Cultural Representations and Signifying Practices. Sage Publications Ltd.

Hook, Sidney. 1992. The Hero in History: A Study in Limitation and Possibility/ Sidney Hook; with a new postscript by the author and a new introduction by Arnold Beichman. New Jersey: Transaction Publisher

Klapp, Orrin E. 1948. The Creation of Popular Heroes dalam American Journal Sociology Vol 54 No. 2 (September 1948), pp. 135 - 141. The University of Chicago Press. A.D. Kirana, Reproduksi Narasi tentang Kepahlawan Soeharto: Studi Representasi... I 137 
Diunduh pada http://www.jstor.org/stable/2771362 pada tanggal 18 Agustus 2016 Jam 15:40 UTC

Kuntowijoyo. 2003. Metodologi Sejarah. Yogyakarta: Tirta Wacana

Loewen, James W. 1995. Lies my teacher told me: everything your American history textbook got wrong. New York: New Press.

Lord, Bary et al, 2012. Manual of Museum Planning 3 ${ }^{\text {r }}$ Editions. USA: Altamira Press

Luke, Timothy. W. 2002. Museum Politics: Power Plays at the Exhibition. USA: University of Minnesota Press

Magnis-Suseno, Franz. 1984. Etika Jawa: Sebuah Analisa Falsafi tentang Kebijaksanaan Hidup Jawa. Jakarta: Gramedia Pustaka Utama

Mulder, Niels. 1978. Mysticism and Everyday Life in Contemporary Java: Cultural Persistence and Change. Singapura: Singapore University Press

Mulder, Niels. 2000. Individu, Masyarakat, dan Sejarah: Kajian Kritis Buku-Buku Pelajaran di Sekolah Indonesia. Yogyakarta: Kanisius.

Pusat Bahasa. 2008. Kamus Besar Bahasa Indonesia Edisi Keempat. Jakarta: Gramedia Pustaka Utama.

Ricklefs, M.C. 2012. Mengislamkan Jawa: Sejarah Islamisasi di Jawa dan Penentangnya dari 1930 sampai sekarang. Jakarta: Serambi

Sarup, Madan. 2008. Panduan Pengantar Untuk Memahami Postrukturalisme dan Posmodernisme. Yogyakarta: Jalasutra

Van Mensch, Peter \& Leontine Meijer Van Mensch, 2011. New Trend in Museology. Celje: Muzej.

Wood, Michael. 2005. Official History in Modern Indonesia: New Order Perceptions and Counterviews. Brill: Leiden

Thesis

Sari, Dwi Puspa Intan. 2014. Kajian Daya Tarik Museum Memorial Jenderal Besar H.M. Soeharto dan Persepsi Pengunjung Terhadap Daya Tarik, Fasilitas Penunjang, Serta Pelayanan Museum. Skripsi Prodi Pariwisata, Fakultas Ilmu Budaya UGM. Unpublished.

Sudarmaji, Tular. 2014. Between Colonial legacies and Grassroots movement: Exploring Cultural Heritage Practice in the Ngadha and Manggarai Region of Flores. Disertasi: Vrije Universiteit Amsterdam.

\section{Artikel Internet}


https://m.tempo.co/read/news/2013/06/08/058486759/ulang-tahun-museum-suhartodiresmikan dilihat pada tanggal 22 April 2016 pukul 15:11 WIB

https://m.tempo.co/read/news/2013/06/17/078488720/hotel-toegoe-akan-menjadi-soehartocenter dilihat pada tanggal 22 April 2016 pukul 15:26 WIB

http://www.tribunnews.com/nasional/2014/01/12/ini-yang-bikin-predikat-jenderal-besaruntuk-sby-banjir-protes

http://tni.mil.id/pages-22-kepangkatan.html

http://www.defense.gov/About-DoD/Insignias/Officers_diunduh tgl. 9 November 2015

http://hmsoeharto.com/tentang-museum/ diakses pada tanggal 3 September 2016 jam 10:40.

UU No. 20 Tahun 2009 diunduh dari http://www.bpkp.go.id/uu/file/2/26.bpkp tanggal 27 Agustus 2016 jam $17: 39)$

http://m.tempo.co/read/news/2016/05/20/078772601/Alasan-Golkar-Ngotot-Usulkan-

Soeharto-Jadi-Pahlawan-Nasional diakses tanggal 3 September 2016 jam 14:42

\section{Narasumber}

Gatot Nugroho, Pengelola Museum HM Soeharto, 49 tahun

Bibit, Penjaga Museum HM Soeharto, 70 tahun.

\section{Lampiran}

Ft. 1. Halaman Depan Museum (2015) Dokumentasi: Penulis

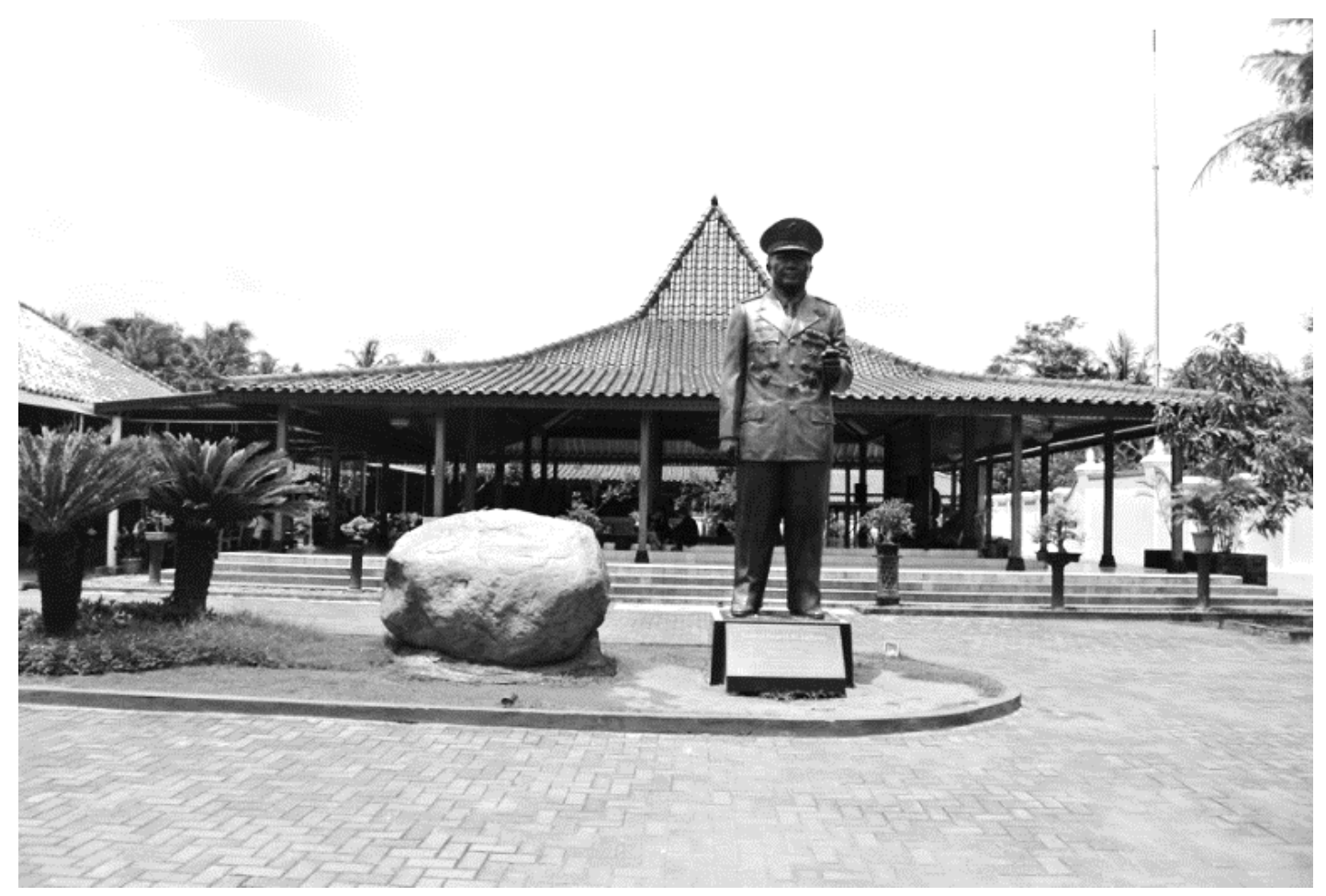




\section{Sasdaya}

Gadjah Mada Journal of Humanities

Ft. 2. Patung Soeharto. Dokumentasi: Penulis

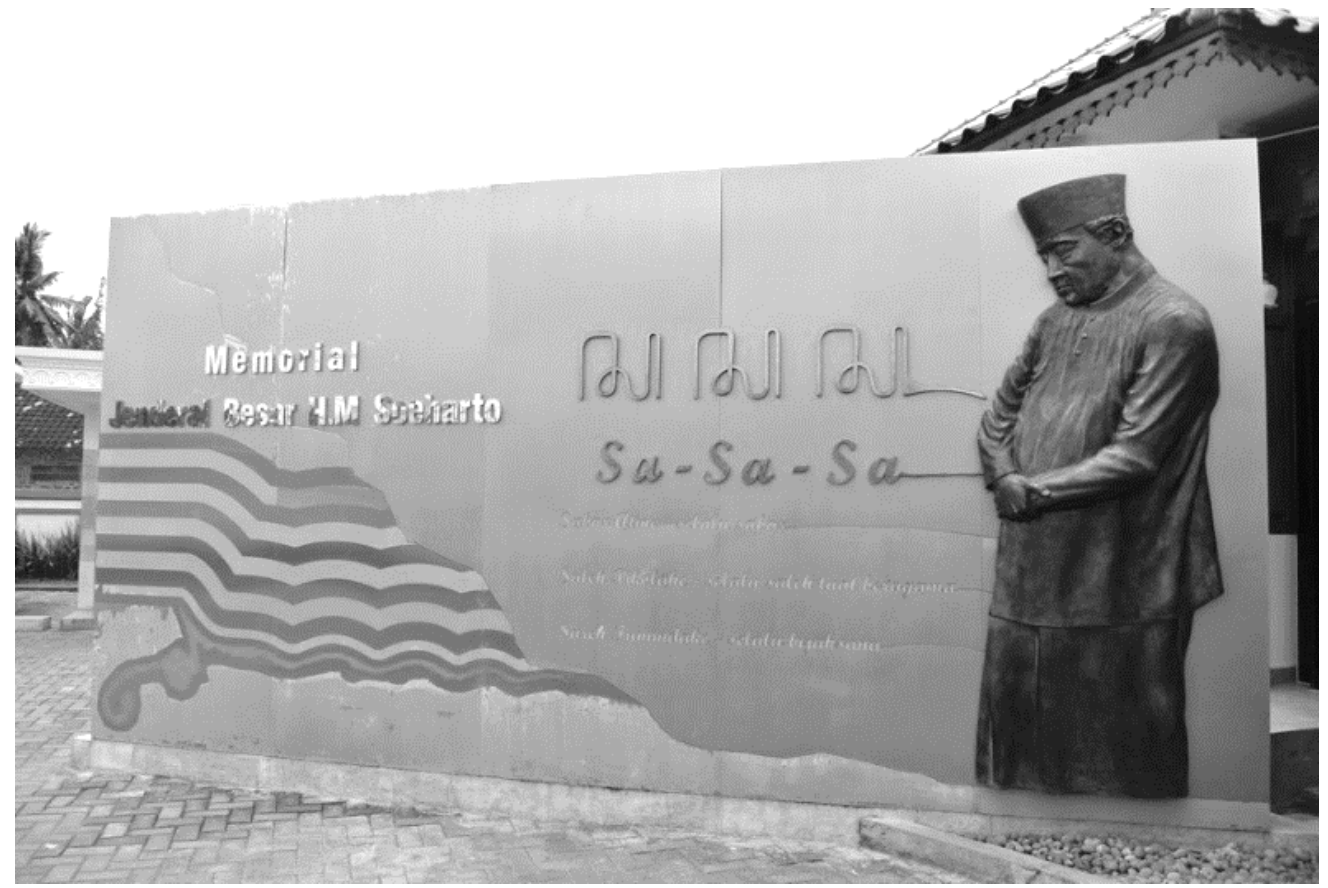

Ft. 3. Displai Pameran Selasar Kesaktian Pancasila. Dokumentasi: Penulis

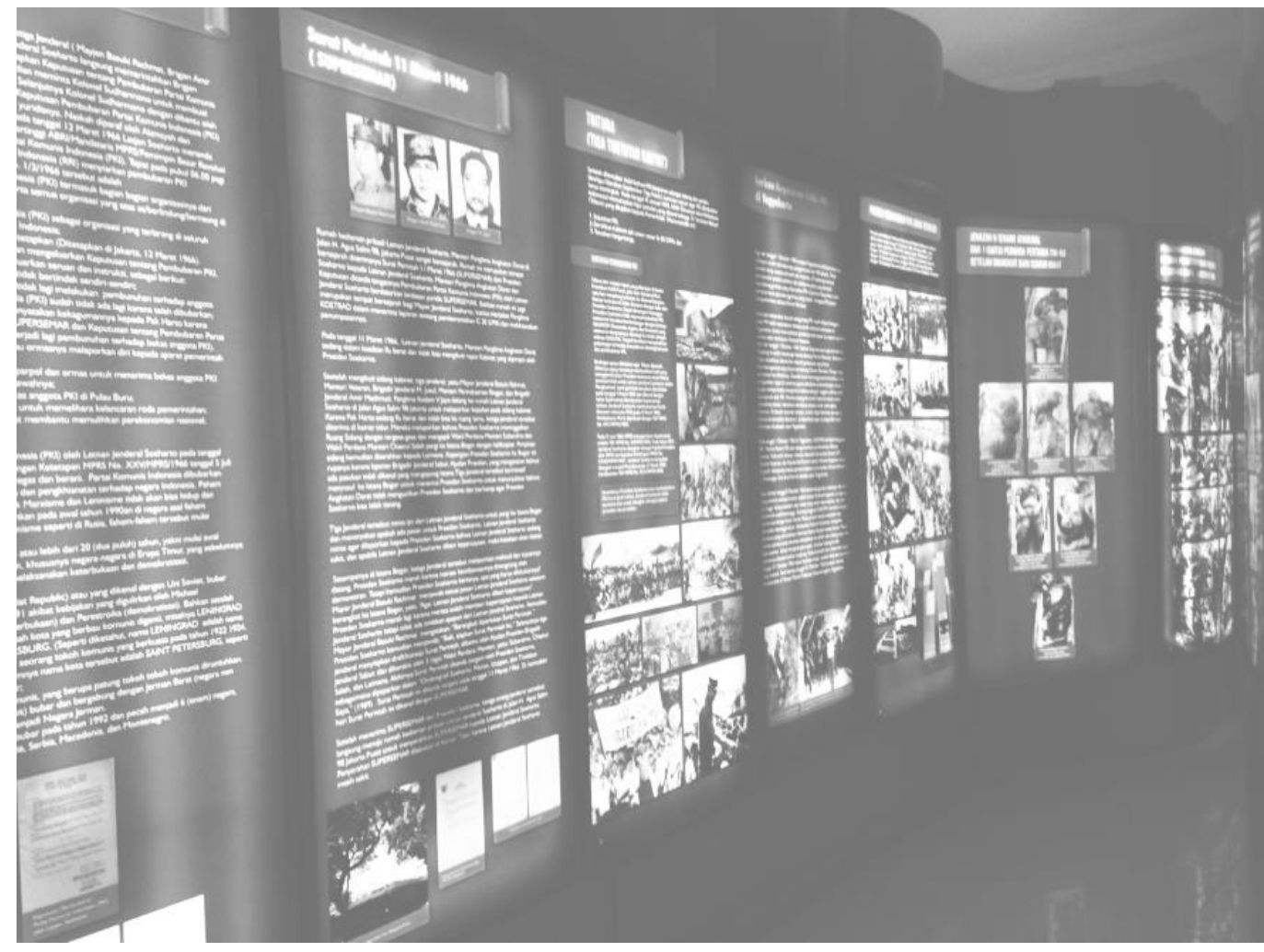

A.D. Kirana, Reproduksi Narasi tentang Kepahlawan Soeharto: Studi Representasi... I 140 